\title{
PRONUNCIATION ERRORS IN STUDENTS' VLOG PROJECTS
}

\author{
Ika Fathin Resti Martanti ${ }^{1}$ \\ ${ }^{1}$ Sekolah Tinggi Teknologi Kedirgantaraan Yogyakarta \\ Email: $\underline{\text { ika.fathin@sttkd.ac.id }}$
}

\begin{abstract}
This research explored the pronunciation errors produced by the students in their vlog projects and the linguistics factors that contributed to their errors. This study employed a descriptive qualitative method. The data were collected from the vlogs made by the students which were uploaded on Youtube channels. The participants were 30 students of the Air Transport Management study program in STTKD Yogyakarta. The data collection technique was done by observation and documentation. The data were analyzed by applying qualitative data analysis. The data were classified using the theory from Bonaventura, Herron, and Menzel (2000). The results showed that there were 67 pronunciation errors existed in the vlog projects. The mispronunciations could be categorized into three types of errors, namely: the problems of non-native sounds as many as $34 \%$, the carry-over of pronunciation regularities from the mother tongue as many as $45 \%$, and the overgeneralization of target language (L2) regularities as many as $21 \%$. It is expected that the findings can help students diagnose their errors and mistakes in English pronunciation and later can motivate them to improve their English proficiencies. Besides, it can help the teachers develop strategies to minimize students' errors in pronunciation.
\end{abstract}

Keywords: Pronunciation, Errors, Vlog

\section{INTRODUCTION}

\subsection{Introduction}

The education field has experienced a great transformation since the Coronavirus Disease (COVID-19) outbreak which had arisen at the end of 2019 and started to become a pandemic for the whole world at the beginning of 2020. Since then, the government has issued a policy for the educational institutions in Indonesia to conduct teaching and learning online. It is in line to prevent the spread of COVID-19 by maintaining social distancing. Nowadays the ability to use technology in teaching and learning becomes one of the key points to survive during the pandemic era of COVID-19. 
Many students who belong to what is so-called Generation Z (Gen Z) are already familiar with the implementation of technology in their lives. Singh and Dangmei (2016: 2) in Dolot (2018) define Gen Zs as generations who were born in the 1990s and raised in the 2000s during the most profound changes in the century who exist in a world with the web, internet, smartphones, laptops, freely available networks, and digital media or known as "digital natives". This generation can function both in the real and virtual world, even can easily switch between these two worlds (Dolot, 2018). This phenomenon is also supported by the existence of social media. Social media now have become a lifestyle that cannot be separated from Gen Z's everyday lives. Social media, such as WhatsApp, Instagram, Facebook, Twitter, etc., not only become a means of communication but also a way to manifest ideas, opinions, and attitudes, and develop personal images through it. Generation Zs have the ability not only to use the content on the internet, but they also have the power to create and control it.

Many teachers have tried to integrate technology into their teaching and learning. One of the ways to enhance students' speaking skills by using technology is through Vlog (Video Blog). A video blog or commonly abbreviated as Vlog is defined as "a web blog (blog) that uses video rather than text or audio as its primary media source (British Columbia, 2005). Vlogs combine pictures, audio, movies, and texts to communicate messages, such as personal feelings, stories, documentaries (Hall, 2004). People who create vlogs are called vloggers. Vloggers usually use a video editing tool/application/software to edit their videos. They may add background music, sound, texts, and any other effects to decorate the video. After the video is ready, then it will be uploaded to the website which hosts the video and the vloggers will get feedback from their audiences through comments. In educational sites, vlogging can give some benefits as a tool for meeting the learning needs of students, making a reflection on learning, demonstrating understandings about various concepts, collaborative work and creating learning communities, digital storytelling, improving media literacy, and student journalism (Hall, 2004).

Nowadays, Youtube has become a major source for vloggers to upload their videos. According to the data statistics taken from the website of We Are Social (2021), the internet users in Indonesia aged 16 to 64 years old who accessed Youtube in January 2021 reached 93,8 \% which is the highest among the other social media platforms. Teachers view this phenomenon as one of the opportunities to develop students' capability regarding both technology and language skills. By giving projects for the students to create Vlogs, it will enhance students' skills as well as creativity. Creating a vlog encourages students to develop the content or ideas, create and edit the video, and then upload the video on the internet sites, such as YouTube. 
In Sekolah Tinggi Teknologi Kedirgantaraan (STTKD) Yogyakarta, English belongs to English for Specific Purposes (ESP) focusing on the aviation field varying in different topics and objectives for each level. ESP is the branch of English language studies concerning the language, discourse, and culture of English language professional communities, as well as professional macro skills involving knowledge and competencies related to disciplinary, academics, or professional domains or specialized groups (Papadima-Sophocleous et al., 2019). English, especially in Air Transport Management Study Program, is taught in Level 1-6 aiming to prepare the students for the working life in Aviation contexts, such as in the Airports, Aircraft companies, or other business fields. Regarding the demand for English in future work, English is categorized as a Practical Course, so students are encouraged to practice more, rather than to learn about the theories. Based on the preliminary observation during the teaching and learning process, many students still find difficulties in learning English, especially speaking skills. They often get difficulties with pronunciation, vocabulary, and grammar. It can be seen from students' performances during the classroom activities.

Students often make errors in pronouncing English vowels and consonants. The researcher finds some pronunciation errors which frequently occur during the learning activities which focus on Cross-Cultural Understanding topics. For instance, the students pronounce the vowel /u:/ as $/ \mathrm{N}$ / like in the word student that should be pronounced as /'stju:.d ə nt/, instead, they pronounced it as /stıdənt/. They also get difficulties in pronouncing the consonant / $\mathrm{t} /$ like in word culture as that should be pronounced as /'kıl.tfor/, but they pronounce it as /kultur/. These errors are in line with the findings of the researches conducted by Frijuniarsi (2018), Simarmata \& Pardede (2018), and Maiza, (2020). Besides, many researchers have studied the effectiveness of vlogs to improve students' speaking skills (Valimbo \& Hartati, 2018; Lestari, 2019; Asyiah, 2019; Putri \& Sari, 2020; Weganofa \& Khoiro, 2021; and Nurviyani \& Rahayu, 2018). One of the advantages of using vlog is that it is fun and interesting and can motivate students to practice their speaking skills (Nurviyani \& Rahayu, 2018). Therefore, this research aims at exploring pronunciation errors made by students in their vlog projects so that they can identify their mistakes and diagnose the factors that contribute to their errors.

\subsection{Research questions}

Two research questions can be formulated in this research, namely:

1. What are the pronunciation errors made by the students in their vlog projects?

2. What are the linguistics factors that contribute to their errors in their vlog projects?

\subsection{Significance of the study}


The results of this research are expected to give benefits for the learners, the English teachers, and future researchers. For the learners, the results will be beneficial to help them understand their difficulties in speaking, especially diagnosing their errors in pronunciation so that they can anticipate for the future. Later on, it will also help them improve their English proficiencies. Meanwhile, for the English teachers, the results can help them to find strategic ways to minimize students' errors in pronunciation. Besides, it also promotes the use of Vlogs as a means for learning English, especially for assessing students' speaking skills. For future researchers, this research can provide information and can become one of the references about error analysis in students' pronunciation errors as well as the use of vlogs as media for learning English.

\section{METHOD}

\subsection{Research Design}

The study employed descriptive qualitative research to determine the kinds of errors in pronunciation and what are the causes of errors made by the students. Nassaji (2015) states that qualitative research and descriptive research are sometimes used interchangeably. He says that the objective of descriptive research is to describe a phenomenon and its characteristics. To collect the data, observation and surveys are often used. Although the data may be gathered qualitatively, the analysis can be quantitative, like by using percentages, frequencies, averages, or other statistics. Meanwhile, qualitative research is more holistic and collect more variety of data from different sources to get a deeper understanding of the participants, including their perspective, opinions, comments, and attitudes toward particular topics. In this study, the data were collected qualitatively and described using percentages. Then they are analyzed according to the linguistics factors that influenced the errors.

In addition, the focus of this study was an error analysis. Richards \& Schmidt (2010) states that error analysis is the study and analysis of the errors made by second language learners. The aims to conduct error analysis are to identify learners' strategies in language learning, to find out the causes of their errors, and to gather information about their difficulties in language learning. When the teachers can analyze the students' errors, it will get easier in creating the learning materials to help cope with the student's difficulties in learning. Furthermore, many studies have examined the errors in students' pronunciations (Sembiring \& Ginting, 2016; Ramasari, 2017; Simarmata \& Pardede, 2018; and Megariani et al., 2020).

\subsection{Samples/Participants}

The participants of the study were the third-semester students of the Air Transport Management Study Program in STTKD Yogyakarta with a total number of 30 students. In this 
case, the samples were taken from Air Transport Management Study Program because the researcher has been teaching at STTKD Yogyakarta and taught Bahasa Inggris III to the students.

\subsection{Instruments}

The data collection technique used in this study were observation and recording. In this study, the data were collected from the Vlogs made by the students as the assignment to be submitted as the final task. The topic was "Cultures from Some Countries around the World". The duration of the video was around 3-5 minutes. The students were asked to create a conversation in pairs and record it in videos. After that, they had to upload the videos to Youtube Channel. After they had succeeded in uploading the videos on Youtube, they copied the URL link and paste it in Google Form provided by the researcher. The researcher observed and analyzed the students' performances by watching the videos through the links they shared. Then the students' pronunciation errors found in the videos were constructed in the form of field notes.

\subsection{Data analysis}

This study employed qualitative data analysis. The data analysis technique employed the stages of qualitative data analysis proposed by Schutt and Chambliss (2013), namely (1) documentation of the data and the data collection process, (2) organization/categorization of the data into concepts, (3) connection of the data to show the influences between the concepts, (4) corroboration/legitimization, by evaluating alternative explanations, and (5) reporting the findings. The data were taken for a week during the Final Semester Test period. The sources of data were 30 vlog projects created by the students of the Air Transport Management study program. Firstly, the data were documented in the form of Youtube videos. Next, the videos were downloaded and analyzed repeatedly to find out mispronunciations that occurred during the performances. The researcher analyzed the videos according to the pronunciation errors and wrote down the errors in the observation sheets. After that, the errors were coded and classified according to three types of pronunciation errors proposed by Bonaventura, Herron, and Menzel (2000), namely: (1) problems in the pronunciations of non-native sounds, (2) carry-over of pronunciation regularities from the mother tongue (L1); and (3) overgeneralizations of the target language (L2).

\section{FINDINGS AND DISCUSSION}

\subsection{Findings}

This section presents the findings of pronunciation errors that occurred in the vlog projects made by students of the Air Transport Management study program in STTKD Yogyakarta. The results showed that there were 67 mispronunciations produced by the students which were caused by some factors. The mispronunciations were then categorized using the theory proposed by 
(Bonaventura et al., 2000). They propose three problem areas in distinguishing students' errors in pronunciation, namely (1) problems in the pronunciations of non-native sounds, (2) carry-over of pronunciation regularities from the mother tongue (L1); and (3) overgeneralizations of the target language (L2).

The first problem i.e. the pronunciation of non-native sounds arises when the speakers are aware of the correct pronunciation in the target language (L2), but they have difficulties in producing the sounds. In other words, they are capable at the competence level or have understood the correct way to pronounce a particular word, yet at the performance level their articulatory constraints them to pronounce properly. Meanwhile, the second problem i.e. carry-over of pronunciation regularities from L1 to L2 mostly occurs at the phonological level. The speakers produced errors, like devoicing of final voiced consonants and spelling-to-sound mapping of the mother tongue. Then, the last type of error which is the overgeneralization of target language is produced in the form of deletions or assimilations of initial and final consonants or vowels when the adjacent phones influence each other.

Using Bonaventura's theory to analyze, there were 23 mispronunciations caused by the difficulties of pronouncing non-native sounds which were equivalent to $34 \%$. In this case, students tend to replace some phonemes which were difficult to pronounce with similar phonemes in their native language. Meanwhile, $45 \%$ of the pronunciation errors were caused by the carry-over pronunciation regularities from the mother tongue (L1). Then, the remaining $21 \%$ of the errors were caused by the overgeneralizations of target language (L2) regularities. The overall result can be seen in Figure 1 below.

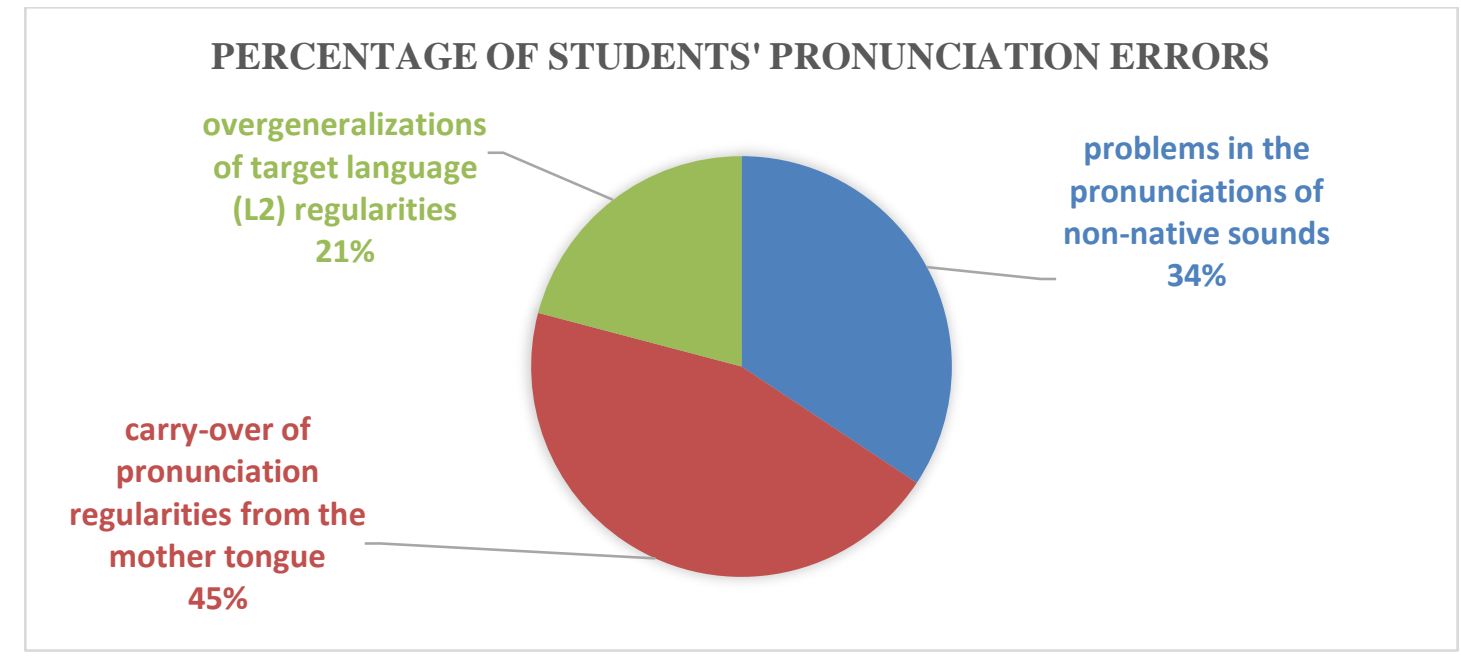

Figure 1. Percentage of Students' Pronunciation Errors 
A more detailed description of the students' pronunciation errors which was classified into three categories of errors is presented below.

\section{Problems in the pronunciations of non-native sounds (Type 1)}

The following table shows some pronunciation errors made by the students caused by the constraints in producing certain phonemes in the target language, as many as 23 mispronunciations. They substituted the phonemes that do not exist in their mother tongue (L1) with similar phonemes. The results can be seen in Table 3.1 below.

Table 3.1 Pronunciation Errors Type 1

\begin{tabular}{|c|c|c|c|}
\hline NO. & WORDS & CORRECT PRONUNCIATION & MISPRONUNCIATION \\
\hline 1. & about & /o'bavt/ & /a'bot/ \\
\hline 2. & although & /०:1'ðәひ/ & /०:1'ðogh/ \\
\hline 3. & culture & /'knltg/ & /kultur/ \\
\hline 4. & cultural & /'kı1.tf ər.əl/ & /kultur $\Lambda \mathrm{l} /$ \\
\hline 5. & education & $/, \operatorname{cdju}(:)^{\prime} \operatorname{ker} \int \partial n /$ & / $\varepsilon d \mathrm{du}^{\prime} \mathrm{k} \varepsilon \int \partial \mathrm{n} /$ \\
\hline 6. & example & /Ig'za:mpl/ & /Eg'sa:mpl/ \\
\hline 7. & European & /,juə.rə'pi:.ən/ & /عrə'piən/ \\
\hline 8. & famous & /'ferməs/ & /'feməs/ \\
\hline 9. & favorite & /'feivərit/ & /f $\Lambda$ vorit/, /fevorit/ \\
\hline 10. & introduce & /,intra'dju:s/ & /introdus/, /introd $\Lambda$ s/ \\
\hline 11. & largest & /'la:dzist/ & /'la:gəst/ \\
\hline 12. & lecturer & /'lektfərə/ & 'lekturər \\
\hline 13. & love & /lıv/ & /lpf/ \\
\hline 14. & main & /mein/ & /main/ \\
\hline 15. & mountain & /'maontin/ & /monteIn/ \\
\hline 16. & music & /'mju:zık/ & /musık/ \\
\hline 17. & ocean & 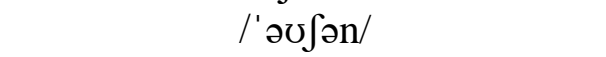 & /'ofən/ \\
\hline 18. & opportunity & / ppə'tju:niti/ & /pppr'tu:niti/ \\
\hline 19. & polite & /po'lait/ & /po'lait/ \\
\hline 20. & state & /steit/ & /stit/ \\
\hline 21. & student & /'stju:dənt/ & /stムdənt/ \\
\hline 22. & talk & /to:k/ & /tolk/ \\
\hline 23. & vacation & /və'keifən/ & /vع'kefən/ \\
\hline
\end{tabular}

According to the data shown in Table 3.1 above, there were 23 errors of the total 67 errors belonged to Pronunciation Errors Type 1 or as many as $35 \%$ of the total amount. The mispronunciations are influenced by Bahasa Indonesia as the student's mother tongue. Some English sounds do not exist in Bahasa Indonesia, thus students found difficulties to produce the sounds. Students tended to substitute the sounds with the closest sounding phonemes which are easier for them to pronounce. For instance, in the word "love", instead of pronouncing it as / $\Lambda \mathrm{v} /$, they pronounced it as /lpf/. They replace sound /v/ which is voiced with the voiceless /f/ sound to simplify the pronunciation. Many students also got difficulties in pronouncing vowel sounds /I/, 
$/ \partial /, / N /$, and $/ \mathrm{s} / /$, such as in the words: example, vacation, culture, and talk. They substitute those sounds with $/ \varepsilon /, / \varepsilon /, / \mathrm{u} /$, and / /. They also had problems in pronouncing diphthongs, such as /av/, /əv/, /es/, and /av/, e.g. in the words: about, although, ocean, famous, state. They replace the diphthongs into monophthongs $/ \mathrm{o} /, / \mathrm{o} /, / \mathrm{o} /, / \varepsilon /$, and $/ \mathrm{I} /$.

\section{Carry-over of pronunciation regularities from the mother tongue (L1) (Type 2)}

The following table shows some pronunciation errors caused by the carry-over of pronunciation regularities from the mother tongue (L1) to the target language (L2). Students tend to pronounce certain sounds in L2 as the sounds from their L1 that they were already familiar with. There were 30 mispronunciations from this category as follows.

Table 3.2 Pronunciation Errors Type 2

\begin{tabular}{|c|c|c|c|}
\hline NO. & WORDS & CORRECT PRONUNCIATION & MISPRONUNCIATION \\
\hline 1. & April & /'eI.prəl/ & / $\Lambda$ pril/ \\
\hline 2. & bow & /bav/ & /bow/ \\
\hline 3. & building & /'bilding/ & /buildin/ \\
\hline 4. & chocolate & /'fpkolit/ & /'tgoklıt/ \\
\hline 5. & color & /'knl.ər / & /'kol.or / \\
\hline 6. & company & /'kımpəni/ & /'kompəni/ \\
\hline 7. & country & /'kıntri/ & /kontri/ \\
\hline 8. & culinary & /'kulınəri/ & /'kulınəri/ \\
\hline 9. & day & /deI/ & $/ \mathrm{d} \Lambda \mathrm{i} /$ \\
\hline 10. & difficulty & /'difıkəlti/ & /'difıkulti/ \\
\hline 11. & disturbed & /dis't3:bd/ & /dis'turbed/ \\
\hline 12. & festival & /'festəvəl/ & /‘festiv $\Lambda \mathrm{l} /$ \\
\hline 13. & high & /haI/ & /haIgh/ \\
\hline 14. & infrastructure & /'Infre, str $\Lambda \mathrm{kt} \partial /$ & /'Infr $\Lambda_{1}$ struktur/ \\
\hline 15. & Japan & /dzo'pæn/ & /јıр $\Lambda \mathrm{n} /$ \\
\hline 16. & July & /dzo'lai/ & /dzo'li/ \\
\hline 17. & knowledge & /'nolids/ & /knowledz/ \\
\hline 18. & management & /'mænidzmənt/ & /mæ'nedzmont/ \\
\hline 19. & many & /'meni// & /'m^ni// \\
\hline 20. & opinion & /ə'pinjən/ & /o'pinion/ \\
\hline 21. & other & /ムðə/ & /pðər/ \\
\hline 22. & plan & /plæn/ & /plın/ \\
\hline 23. & served & /s3:vd/ & /served/ \\
\hline 24. & Singapore & /singe'po:/ & /,sina'po:r/ \\
\hline 25 . & taste & /teist/ & /test/ \\
\hline 26. & tower & /'tavə/ & /'towər/ \\
\hline 27. & tribes & /traibz/ & /tribes/ \\
\hline 28. & try & /trai/ & /tri/ \\
\hline 29. & want & /wpnt//wa:nt/ & /won/ \\
\hline 30. & watching & /'wotgin/ & /wstchin/ \\
\hline
\end{tabular}


As shown previously in Figure 1, Pronunciation Errors Type 2 was the more frequent errors produced by the students, as many as $45 \%$ of the total mispronunciations. It showed that students tended to carry-over pronunciation regularities from their first language or Bahasa Indonesia. It usually involves phonological changes, like the devoicing of final stop consonants or the spellingto-sound mapping of the mother tongue (Megariani et al., 2020). Students pronounced the words April and July as that should be pronounced as /'er.prol/ and /dzo'lai/ instead they pronounced them as / $\Lambda$ pril/ and /dzv'li/. It might happen because they had similar words in Bahasa Indonesia with the same meanings. They were already familiar with the pronunciation of those words in their mother tongue then carried over the same pronunciation to the target language (L2) or English. The same phenomenon occurred with the words: chocolate, infrastructure, culinary, festival, management, opinion, and Singapore. Besides, the students still also brought the pronunciation of the vowels in Bahasa Indonesia into English. It could be found when they pronounced the words "bow, color, other, tower, day, many, and watching". They pronounced the phoneme /o/ and /a/ as what existed in Indonesian pronunciation. The word bow should be pronounced as /bav/, instead, they pronounced it as /bow/. The word color should be pronounced

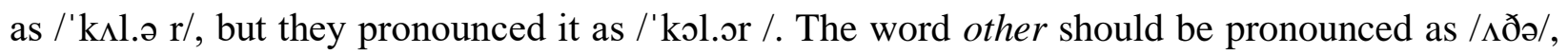
but they pronounced it as /pðər/. The same also occurred in the word tower that should be pronounced as /'tavə/, but it was pronounced as /'towər/. They also pronounced the phoneme /a/ as it was written and as what they already had in Bahasa Indonesia. The word day should be pronounced as $/ \mathrm{deI} /$, but they pronounced it as $/ \mathrm{d} \Lambda \mathrm{i} /$. The word many should be pronounced as /'meni/, but they pronounced it as /'m^ni/ just like the pronunciation of the word money. The same error also happened in the word watching which should be pronounced as /'wptfin/, but they pronounced it as /wntchip/. They ignored the variety in the English pronunciation system that the same letter may have different types of pronunciation.

Another example of errors in this type is the pronunciation of the word "want". This word is pronounced as /wpnt/ in British English and /wa:nt/ in American English. However, the students pronounced it as /wpn/. They devoiced the final consonant/t/ and omitted it. It was caused by the orthography in Bahasa Indonesia which rarely has a word with a consonant cluster at the end of the word, like /nt/ in the word/want/. This finding was also in line with the previous study by (Megariani et al., 2020) which found the same type of error in the word /ask/ that should be pronounced as /a:sk/ in British English and /æsk/ in American English, instead, students pronounced it as /a:s/.

\section{Overgeneralizations of target language (L2) regularities (Type 3)}


The errors of students' pronunciation errors type 3 were caused by overgeneralization of the target language. The number of errors for this type amounted to 14 , reaching $21 \%$ of the total errors. A detailed description of Type 3 errors can be seen in Table 3.3. as follows.

Table 3.3 Pronunciation Errors Type 3

\begin{tabular}{|c|c|c|c|}
\hline NO. & WORDS & CORRECT PRONUNCIATION & MISPRONUNCIATION \\
\hline 1. & bridge & /bridz/ & /braidg/ \\
\hline 2. & business & /'biznis/ & /'bszInIs/ \\
\hline 3. & ceremony & /'ser.I.mə.ni/ & /'ker.e.mp.ni/ \\
\hline 4. & during & /'djvə.rıy//'dor.ın/ & /'d $\Lambda$ rIy/ \\
\hline 5. & English & /'In.glig/ & /'cy.glif/ \\
\hline 6. & event & /I'vent/ & /'i:.v ə $\mathrm{n} /$ \\
\hline 7. & introduce & /, Intrə' dju:s/ /, Intrə' du:s/ & /introdus/, /introd $\Lambda$ s/ \\
\hline 8. & island & /'arlənd/ & /'islen/ \\
\hline 9. & live (v) & /liv/ & /laif/ \\
\hline 10. & present (v) & /pri'zent/ & /presənt/ \\
\hline 11. & since & $/ \sin t \mathrm{~s} /$ & /sains/ \\
\hline 12. & student & /'stju:dənt/ & /stıdənt/ \\
\hline 13. & subscribe & /səb'skraib/ & /s $\Delta$ b'skraib/ \\
\hline 14. & the + vowel & /ði:/ & /ðə/ \\
\hline
\end{tabular}

Based on the data shown in Table 3.3, it could be seen that out of 67 pronunciation errors, 14 errors belonged to Type 3 errors. It indicated that students tend to overgeneralize the pronunciation of particular words into the adjacent phonemes. The students applied possible pronunciations to unsuitable words. Students tended to apply similar sounds that they knew in pronouncing other words which contain the same letters.

Students' errors that belonged to Type 3 could be exemplified as when they pronounced the word "business". They were already familiar with the word "bus" which should be pronounced

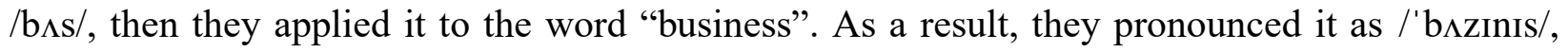
instead of /'biznis/. Furthermore, they also applied the same rule for the word "island". They already understood the pronunciation of the word "land" as /lænd/, then they applied it to the word "island". According to British and American English, this word is pronounced as /'arlənd/, but they pronounced it as /'islen/. Moreover, they also omitted the final consonant/d/ in this word.

The other examples of students' errors in overgeneralizing the pronunciation could be seen from their mispronunciations of the words "introduce" and "student". They were already familiar with the word introduction (the Noun form of the verb introduce), which is pronounced as /, In.trə' $\mathrm{d} \Lambda \mathrm{k}$. $\int$ ə $\mathrm{n} /$, so they generalized the pronunciation of the word introduce into /Introdus/ or /introd $\Lambda \mathrm{s} /$. Meanwhile, for the word student, they pronounced it as /st $\Lambda$ dənt/ because they brought up the pronunciation from the word study which is /'st $\Lambda$ d.i/. They substituted the phoneme /u/ in the word student with the phoneme / $\mathrm{N}$ like in the word study. 


\subsection{Discussion}

In speaking activities, it is common for students to make errors and mistakes, especially about pronunciation. Errors can be defined as the failure in using the system of language correctly (Ramasari, 2017). In this case, students are not aware of the language system existing in the target language (L2), thus they consistently make errors without fully understanding the correct rules. The errors occur because of the students' lack of English knowledge, competencies, and comprehension. Meanwhile, a mistake is defined as the failure in using the language system correctly because of some factors, like hesitation, slips of tongue, carelessness, memory lapses, or physical condition (Ramasari, 2017). By understanding each concept, it will be advantageous for teachers to help their students overcome their constraints as well as to improve their oral performances.

In studying students' errors in pronunciation, it is significant to study the interference of the students' mother tongue into the students' oral performances. Based on the results of the study, it can be inferred that students' mother tongue i.e. Bahasa Indonesia influences their pronunciation in English. The results indicated that most of the pronunciation errors were caused by the carryover of pronunciation regularities from the mother tongue shown from the percentage of the errors i.e. 30 pronunciation errors or $45 \%$ of the total 67 errors. The orthography system of Bahasa Indonesia also gave influences to the production of the sounds.

In addition, students' pronunciation errors can also be caused by some factors. Velikaya (2017) proposes four groups that cause students' errors in pronunciation, namely: (1) mistakes in consonants, (2) mistakes in vowel sounds, (3) mistakes in word stress, and (4) mistakes in intonation. These mistakes occurred because of the interference of the students' first language. Students should be aware that to speak like a native speaker they not only try to imitate native speakers but also to adjust their organ of speech for the tense articulations of English words. Furthermore, the findings are in line with the studies from (Zedadra et al., 2019)

\section{CONCLUSIONS}

\subsection{Conclusion}

This research analyzed the errors of students' pronunciations in Vlog projects and the linguistic factors that contribute to the errors. Based on the findings, there were 67 mispronunciations in the Vlogs. The mispronunciations were categorized into three types, namely (1) problems in the pronunciations of non-native sounds, (2) carry-over of pronunciation regularities from the mother tongue (L1), and (3) overgeneralizations of target language (L2) 
regularities. Most of the pronunciation errors were caused by the carry-over of pronunciation regularities from the mother tongue shown from the percentage of the errors i.e. 30 pronunciation errors or $45 \%$ of the total 67 errors.

\subsection{Suggestions}

Based on the results of this study, there are some suggestions for the teachers, the learners, as well as future researchers. Identifying students' errors in learning can be a means to understand students' difficulties in learning English. It will help teachers develop strategies to minimize students' errors, including the method or the technique, the media, and the materials, to facilitate students in dealing with their errors. The teachers may also provide error correction by giving direct feedback (the teachers supply the correct form) or indirect feedback (the teachers point out the problem and ask the learners to correct it if possible). For the learners themselves, identifying their errors in pronunciation can help them improve their English skills. Minimizing their errors in speaking can improve their language performances. Meanwhile, for future researchers, it is suggested to explore more and conduct different types of research related to students' speaking skills.

\section{REFERENCES}

Asyiah, N. (2019). ENHANCING STUDENTS’ INTEGRATED LISTENING-SPEAKING COMPETENCE THROUGH VIDEO BLOG (VLOG): A Classroom Action Research Conducted at the English Department Students Universitas Ahmad Dahlan. 1-7. http://eprints.uad.ac.id/14883/

Bonaventura, P., Herron, D., \& Menzel, W. (2000). Phonetic rules for diagnosis of pronunciation errors. Konvens 2000. Sprachkommunikation, Vorträge Der Gemeinsamen Veranstaltung 5, 225-230. http://nats-www.informatik.unihamburg.de/ wolfgang/papers/konvens2000.ps.gz

British Columbia. (2005). 7 Things You Should Know about Videoblogging. Educause Learning Initiative : Advancing Learning Through IT Innovation.

Dolot, A. (2018). The characteristics of Generation Z. E-Mentor, 74, 44-50. https://doi.org/10.15219/em74.1351

Frijuniarsi, N. (2018). Error in Vowel Pronunciation Made by Informatics Students. Scope : Journal of English Language Teaching, 2(02), 149. https://doi.org/10.30998/scope.v2i02.2460

Hall, N. L. (2004). The Promises of Videoblogging in Education Evrim Baran Center for Technology in Learning and Teaching Department of Curriculum and Instruction. 10-18.

Lestari, N. (2019). Improving the Speaking Skill by Vlog (video blog) as Learning Media: The EFL Students Perspective. International Journal of Academic Research in Business and Social Sciences, 9(1), 915-925. https://doi.org/10.6007/ijarbss/v9-i1/5490 
Maiza, M. (2020). An Analysis of Students' Pronunciation Errors. JOEEL: Journal of English Education and Literature, 1(1), 18-23. https://doi.org/10.38114/joeel.v1i1.27

Megariani, Y. M., Listyantari, N. A., \& Bram, B. (2020). Mispronunciations in Graduate Students' Presentation Projects. Metathesis: Journal of English Language, Literature, and Teaching, 4(1), 56. https://doi.org/10.31002/metathesis.v4i1.1879

Nassaji, H. (2015). Qualitative and descriptive research: Data type versus data analysis. Language Teaching Research, 19(2), 129-132. https://doi.org/10.1177/1362168815572747

Nurviyani, V., \& Rahayu, A. S. (2018). a Study of Students' Speaking Skill Through Vlog. Jurnal JOEPALLT (Journal of English Pedagogy, Linguistics, Literature, and Teaching), 6(2). https://doi.org/10.35194/jj.v6i2.398

Papadima-Sophocleous, S., Kakoulli Constantinou, E., \& Giannikas, C. N. (2019). ESP teaching and teacher education: current theories and practices. In ESP teaching and teacher education: current theories and practices. Research-publishing.net. https://doi.org/10.14705/rpnet.2019.33.9782490057450

Putri, N. E., \& Sari, S. Y. (2020). Applying Vlog Assignment to Develop Students' Speaking Ability. 411(Icoelt 2019), 280-283. https://doi.org/10.2991/assehr.k.200306.046

Ramasari, M. (2017). Students Pronounciation Error Made in Speaking for General Communication. Linguistic, English Education and Art (LEEA) Journal, 1(1), 37-48. https://doi.org/10.31539/leea.v1i1.32

Richards, J. C., \& Schmidt, R. (2010). Dictionary of language teaching and applied linguistics. In Proceedings of the 21st Asian Pacific Weed Science Society (APWSS) Conference, 2-6 October 2007, Colombo, Sri Lanka.

http://search.ebscohost.com/login.aspx?direct=true\&db=lah\&AN=20163298076\&site=ehos $\mathrm{t}-$ live\%0Ahttp://www.cabi.org/cabdirect/showpdf.aspx?PAN=http://www.cabi.org/cabdirect/ showpdf.aspx?PAN=20163298076\%0Aemail: javaidleghari@ hotmail.com

Schutt, R. K., \& Chambliss, D. F. (2013). Chapter 10: Qualitative Data Analysis. Making Sense of the Social World: Methods of Investigation, 320-357. https://doi.org/10.1136/ebnurs.2011.100352

Sembiring, N., \& Ginting, A. F. Y. (2016). An Analysis of Pronunciation Errors Made by the Fourth Semester Students of English Education Study Program at UNIKA. Jurnal Suluh Pendidikan FKIP-UHN, 3(1).

Simarmata, D., \& Pardede, H. (2018). Error Analysis Of Students' Pronunciation in Pronouncing English Vowels And Consonants. Lampung: Journal Smart, 4(1), 1-38.

Valimbo, I. A., \& Hartati, E. (2018). Vlog To Improve Students Speaking Skill : a Classroom Action Research. Konferensi Pendidikan Nasional, 91-97.

Velikaya, E. (2017). Pronunciation errors : is it possible to eliminate them? January 2010.

We Are Social. (2021). Digital 2021. Global Digital Insights, 103.

Weganofa, R., \& Khoiro, I. (2021). The Effectiveness of Video Blog (VLOG) on Students' 
Speaking Skill. Proceedings of the 2nd Annual Conference on Social Science and Humanities (ANCOSH 2020), 542(Ancosh 2020), 211-214.

https://doi.org/10.2991/assehr.k.210413.049

Zedadra, O., Guerrieri, A., Jouandeau, N., Seridi, H., Fortino, G., Spezzano, G., Pradhan-Salike, I., Raj Pokharel, J., The Commissioner of Law, Freni, G., La Loggia, G., Notaro, V., McGuire, T. J., Sjoquist, D. L., Longley, P., Batty, M., Chin, N., McNulty, J., TVERSK, K. A. A., ... Thesis, A. (2019). No 主観的健康感を中心とした在宅高齢者における 健康 関連指標に関する共分散構造分析Title. In Sustainability (Switzerland) (Vol. 11, Issue 1). http://scioteca.caf.com/bitstream/handle/123456789/1091/RED2017-Eng8ene.pdf? sequence=12\&isAllowed=y\%0Ahttp://dx.doi.org/10.1016/j.regsciurbeco.2008.06. 005\%0Ahttps://www.researchgate.net/publication/305320484_SISTEM_PEMBETUNGAN _TERPUSAT_STRATEGI_MELESTARI 